\title{
Posttraining androgens' enhancement of cognitive performance is temporally distinct from androgens' increases in affective behavior
}

\author{
CHERYL A. FRYE and ELIZABETH H. LACEY \\ State University of New York, Albany, New York
}

\begin{abstract}
Steroid hormone-induced variations in spatial learning and memory tasks have been reported. In this study, androgens' effects in various cognitive and affective tasks were investigated in order to determine whether any observed differences in cognitive performance could be due to affective changes produced by the hormones. Ovariectomized rats $(N=72)$ received $0.0,3.0$, or $7.5 \mathrm{mg} / \mathrm{kg}$ subcutaneously, of testosterone (T), dihydrotestosterone (DHT), or $5 \alpha$-androstane- $3 \alpha, 17 \beta$-diol ( $3 \alpha$-Diol) suspended in $10 \%$ ethanol/sesame oil v/v. For the cognitive tasks (Y maze, inhibitory avoidance, and object recognition), subjects were injected after training trials. For the affectivetasks (open field, elevated plus maze, and tailflick), subjects were injected 1 or $24 \mathrm{~h}$ before testing. Posttraining injections that produced physiological concentrations of androgens - T, DHT, and $3 \alpha$-Diol - $1 \mathrm{~h}$ later increased the percentage of correct choices in the Y maze, the latencies to cross to the shock-associated side of the inhibitory avoidance chamber, and percentage of time exploring novel objects $24 \mathrm{~h}$ later, when androgen levels were no longer increased. Administration of T, DHT, and $3 \alpha$-Diol also increased the number of entries into the center squares of a brightly lit open field, open-arm time in the elevated plus maze, and tailflick latencies 1 but not $24 \mathrm{~h}$ following administration. These findings suggest that these androgens, when administered following training, can enhance cognitive performance in the tasks investigated $24 \mathrm{~h}$ later when androgen levels nadir, but overt changes in the affective behaviors examined occurred at the time of physiological concentrations $1 \mathrm{~h}$ but not $24 \mathrm{~h}$ following androgen administration. These findings suggest posttraining androgens can enhance consolidation and cognitive performance, independent of their anxiolytic actions.
\end{abstract}

Some studies of sex differences in rodents' spatial learning and memory (Joseph, Hess, \& Birecree, 1978; Maren, De Oca, \& Fanselow, 1994) indicate that males perform better than females in mazes (Beatty, 1984; Dawson, 1972; Frye, 1995; Gaulin \& Fitzgerald, 1989; Stewart, Skvarenina, \& Pottier, 1975; Williams \& Meck, 1991) and in spatial-contextualconditioning tasks (Maren et al., 1994). These sex differences have been attributed to testosterone's organizational effects (Isgor \& Sengelaub, 1998; Williams, Barnett, \& Meck, 1991) on later information processing (Squire, 1992) or performance strategies. Activational effects of sex hormones, which fluctuate over the estrous cycle, may contribute to sex differences in spatial ability. For example, in a delayed nonmatchingto-sample radial-arm maze task that utilizes a food reward, rats performed more slowly on proestrus days than on any other estrous cycle day, although there are no dif-

This research was supported by Grant 96-10 from the Whitehall Foundation. Additional support was provided by Grant 95-14463 from the National Science Foundation. The assistance of Trent Reed on the pilot studies investigating $3 \alpha$-Diol was appreciated. Correspondence concerning this article should be addressed to C. A. Frye, Department of Psychology, Biological Sciences \& the Center for Neuroscience Research, the University at Albany-SUNY, 1400 Washington Avenue, Albany, NY 12222 (e-mail: cafrye@ cnsunix.albany.edu). ferences in errors across the estrous cycle (Stackman, Blasberg, Langan, \& Clark, 1997). Rats in proestrus show less spatial-contextual conditioning than male or estrous rats (Markus \& Zecevic, 1997; Sfikakis, Spyraki, Sitaras, \& Varonos, 1978). In an aversively motivated spatial memory task in the water maze, minor decrements (Frye, 1995; Galea, Kavaliers, Ossenkopp, \& Hampson, 1995; Warren \& Juraska, 1997) or no differences (Berry, McMahan, \& Gallagher, 1997; Frye, 1995; Warren \& Juraska, 1997) have been found during proestrus compared with other phases of the cycle.

Activational effects of gonadal steroids during training on learning and memory are more evident in experimentally controlled situations than across the estrous cycle, which is associated with endogenous variations in many steroids and physiological parameters. Estradiol (E) can influence performance on tasks of learning and memory when administered to ovariectomized (ovx) rats. For example, E improves performance on tasks of spatial memory such as the radial-arm maze task (Daniel, Fader, Spencer, \& Dohanich, 1997; Daniel, Roberts, \& Dohanich, 1999; Luine, 1997; Luine, Richards, Wu, \& Beck, 1998; Luine \& Rodriguez, 1994; Packard, 1998). However, some tasks of spatial reference memory tend to be impaired by E administration (Daniel et al., 1999) or, in 
some cases, by high or endogenous variations in $\mathrm{E}$ (Frye, 1995; Fugger, Cunningham, Rissman, \& Foster, 1998; Galea et al., 1995; Warren \& Juraska, 1997). Interestingly, $\mathrm{E}$ administration does not mimic the full complement of endogenous variations in cognitive and affective (Frye, Petralia, \& Rhodes, 2000) behaviors that have been observed over the estrous cycle. Other hormones, in addition to $\mathrm{E}$, that change over the cycle may alter cognitive and affective performance; however, they have not been the subject of much investigation. Recently, we have found that posttraining administration of progestins enhance consolidation and thereby cognitive performance and that this effect is independent of progestins' anxiolytic actions (Frye \& Lacey, 2000).

Just as endogenous changes in $\mathrm{E}$ or $\mathrm{E}$ administration can influence cognitive and affective behavior, androgens may have similar effects. There is evidence that androgens enhance performance on spatial cognitive tasks in men and women (Christiansen \& Knussmann, 1987; Gouchie \& Kimura, 1991; McKeever \& Deyo, 1990). In female rodents, testosterone (T), its $5 \alpha$-reduced metabolite, dihydrotestosterone(DHT), and its $3 \alpha$-hydroxysteroid reduced metabolite, $5 \alpha$-androstane- $3 \alpha, 17 \beta$-diol ( $3 \alpha$-Diol) normally vary over the estrous cycle (Erskine, Hippensteil, \& Kornberg, 1992) and, like E, influence reproductive behavior (Erskine, 1989; Frye, Duncan, Basham, $\&$ Erskine, 1996). Administration of $3 \alpha$-Diol can also produce analgesia (Frye, van Keuran, Rao, \& Erskine, 1996a) that is similar to that seen over the estrous cycle (Frye, Bock, \& Kanarek, 1992; Frye et al., 2000). Although androgens' organizational effects are known to produce sex differences in spatial learning and memory, and estrogen, an aromatized metabolite of T, given immediately posttraining, enhances consolidation of a spatial water maze task (Packard, 1998; Packard \& Teather, $1997 \mathrm{a}, 1997 \mathrm{~b}$ ), the $5 \alpha$-reduced androgens have yet to be examined extensively for their activational effects on cognitive or affective behavior. Recently, it was shown that $3 \alpha$-Diol administration to ovx rats produced greater increases in cross-over latencies in the inhibitory avoidance paradigm than did E administration (Frye, 2001; Frye \& McCormick, 2000).

This set of experiments was designed to examine whether (1) T and its $5 \alpha$-reduced metabolites alter memory consolidation and thereby cognitive performance when tested $24 \mathrm{~h}$ after hormone injection (to assess hormones' effects on cognitive tasks, ovx rats were administered androgens following short-term habituation and training in the $\mathrm{Y}$ maze, inhibitory avoidance, and object recognition tasks), (2) the presence of $5 \alpha$-reduced androgens influence anxiolysis/analgesia (1-h test), and (3) this influence contributes to the enhancement of memory (24-h test). To address whether hormones influence performance on cognitive tasks owing to changes in affective behavior, the hormones' effects on anxiety and activity measures were examined 1 and $24 \mathrm{~h}$ following steroid administration.

\section{METHOD}

The methods were pre-approved by the Institutional Animal Care and Use Committee.

\section{Animals and Housing}

Female, Long-Evans rats $(N=72)$, approximately 55 days of age, were obtained from Harlan Sprague-Dawley and were housed in hanging stainless steel cages $(24 \times 18 \times 19 \mathrm{~cm})$ in a temperaturecontrolled room $\left(21^{\circ} \pm 1^{\circ}\right)$ in the laboratory animal care facility. The rats were maintained on a 12:12 h light:dark cycle (lights off at 8:00 am) and had access to Purina Rat Chow, Froot Loops (on occasion), and tap water in their home cages.

In females, the primary source of steroid hormones are the ovaries. Hence, the ovaries of all subjects were removed under Ketamine $(75 \mathrm{mg} / \mathrm{kg})$ and Rompun $(12 \mathrm{mg} / \mathrm{kg})$ anesthesia. Following bilateral incisions, the ovaries were isolated, ligated, and removed. The subjects recovered for 2 weeks prior to behavioral testing.

\section{Injection Regimen}

The rats ( $n=8$ per condition) were assigned randomly to receive $0.0,3.0$, or $7.5 \mathrm{mg} / \mathrm{kg}$, SC of T, DHT, or $3 \alpha$-Diol suspended in $10 \%$ ethanol/sesame oil v/v. These dosages were chosen to produce physiological levels of circulating androgens (Erskine et al., 1992; Frye, van Keuran, \& Erskine, 1996). For the Y-maze, inhibitory avoidance, and object recognition tests, the subjects were injected after training trials. The subjects were tested in the open field, elevated plus maze, and tailflick tasks, $1 \mathrm{~h}$ after injection and again $24 \mathrm{~h}$ later. All rats were assigned to an androgen dosage and were tested in each behavioral assay according to their assigned androgen. The order in which the rats were exposed to each behavioral test was counterbalanced in order to prevent order effects and test decay effects on the affective tasks. There was a minimum of a 1-week hormone wash-out period between each behavioral test.

\section{Behavioral Testing}

The following cognitive tasks were utilized for a number of reasons. These tasks assess different types of memory (spatial and nonspatial) and, along with the hormone regimen utilized, allow different mneumonic effects (consolidation and acquisition) to be examined. Tasks were chosen in which the subjects would require only minimal habituation and training prior to testing. Our goal was to investigate the activational affects of androgens on cognitive performance; hence, cognitive tasks that do not require extensive training were utilized, as such training might have precluded or masked any of the effects of the androgens on performance. All data were collected by trained observers, who were blind with respect to treatment conditions. The methods were as previously described (Frye \& Lacey, 1999, 2000; Frye et al., 2000).

Y-maze task. The delayed nonmatching-to-sample Y-maze procedure was utilized as previously described (Aggleton, Hunt, \& Rawlins, 1989; Frye \& Sturgis, 1995; Kelsey, Sanderson, \& Frye, 2000). The $Y$ maze consisted of a start arm $(61 \mathrm{~cm} \mathrm{long} \times 13 \mathrm{~cm}$ wide $\times 30 \mathrm{~cm} \mathrm{high})$ and two goal boxes $(46 \times 15 \times 30 \mathrm{~cm})$ with metal cups (1-cm diameter) positioned $0.5 \mathrm{~cm}$ from the end of each arm. A guillotine door enclosed the start box and each goal arm.

Habituation (Day 1). Rats were ad-lib food restricted for $60 \mathrm{~h}$ prior to habituation and throughout testing. During this time, the rats were given three pellets of rodent chow and three Froot Loops daily. On Day 1, the rats explored the maze without the doors for 2 min and ate $1 / 2$ a Froot Loop placed at the end of each goal arm. The rats were then placed in the start box with the door down. After $5 \mathrm{sec}$, the door was lifted and then closed after they passed it, and they were again allowed to eat the Froot Loops.

Training (Day 2). The rats were trained to alternate between the two goals arms of the maze and were placed in the start box with 
the door down. One goal arm was closed, while the other was open and baited. After $5 \mathrm{sec}$, the start door was lifted and then closed when the rats traversed it. Upon entering the open goal arm, the door was closed, and the rats remained in the arm to eat the bait $(25 \mathrm{sec})$. This forced run was repeated once for the opposite arm then again for the original arm, until the rats alternated three times in succession in under $2 \mathrm{~min}$ for each trial. There were no differences between groups in the latencies for these trials; average latencies were $98.6 \pm 10.9 \mathrm{sec}$. Immediately following the third training trial, the rats were injected with T, DHT, or $3 \alpha$-Diol (0.0., 3.0, or $7.5 \mathrm{mg} / \mathrm{kg} \mathrm{SC}$ ).

Testing (Days 3 and 5). The subjects were tested $24 \mathrm{~h}$ following training (Day 3), and again $48 \mathrm{~h}$ later to test long-term memory (Day 5) for alternating between arms of the maze within 10 trials. On both days, the latency to the goal box and the percentage of correct arm entries in 10 trials were measured. A testing trial consisted of a forced run immediately followed by a choice run. During a forced run, one goal arm was closed, while the other was open and baited. In the second part of the trial, during the choice run, both goal arm doors were open, and the rats could choose either arm. If they chose the correct arm, the arm not previously entered, the rats were closed in the goal box and removed after they ate. In the case of an incorrect choice, defined as a return to the arm just visited, the door was shut behind the rats, and the rats remained for $25 \mathrm{sec}$ without being given a Froot Loop. There was an intertrial interval of $3 \mathrm{~min}$, and the forced arm direction was alternated so that the rats were forced down each arm five times.

Data presented are for choice trials, which are a more sensitive measure of cognitive performance than are forced trials. The latency to reach the food cup in forced runs may be considered a measure of motor behavior and motivation. The percentage of correct choices on the choice runs is considered a measure of memory; hence, overall (Days 3 and 5, since there were no differences in performance on these 2 days) percent correct data are presented for each androgen. One way analyses of variance (ANOVAs) were used to examine the effects of androgen dosage on the percentage of correct choices.

Inhibitory avoidance. The step-through inhibitory avoidance procedure was done according to the methods of O'Connell, Earley, and Leonard (1994) and Frye and McCormick (2000). The apparatus consisted of a two-compartment $(24 \times 18 \times 19 \mathrm{~cm}$ each $)$ stainless steel box similar to that described by Venault et al. (1986) and Frye and McCormick. One chamber was brightly lit from above and was painted white. The other was painted black and was covered in order to block out light. The two chambers were separated by a guillotine door.

Habituation and training (Day 1). The rats were placed in the white chamber with the door down for $5 \mathrm{sec}$. The door was raised as soon as the rats were facing it, and the rats were then allowed to explore the entire box for $2 \mathrm{~min}$. Twenty minutes later, the rats were placed in the white chamber for $5 \mathrm{sec}$ or until they faced the door. When the door was lifted, the rats entered the black compartment, and the door was closed behind them. The rats then received a mild shock ( $0.25 \mathrm{~mA}, 2$-sec duration). There were no differences between groups in the latency to enter the dark side on the training day (average latency was $69.5 \pm 30.6 \mathrm{sec}$ ). Following training, the rats were immediately removed and injected with a given dose of T, DHT, or $3 \alpha$-Diol $(0.0,3.0$, or $7.5 \mathrm{mg} / \mathrm{kg} \mathrm{SC})$.

Testing (Day 2). Twenty-four hours later, the rats were placed in the white chamber. The door was lifted, and the latency to enter the dark chamber was recorded (180 sec maximum).

One-way ANOVAs followed by student Newman-Keuls (SNK) post hocs were used to determine differences in latency for animals injected with $0.0,3.0$, and $7.5 \mathrm{mg} / \mathrm{kg} \mathrm{T,} \mathrm{DHT}$, and $3 \alpha$-Diol.

Object recognition task. The object recognition task was adapted from McCormick, McNamara, Mukhopadhyay, and Kelsey (1997). The object recognition box was $70 \mathrm{~cm}$ wide $\times 70 \mathrm{~cm}$ long with two objects placed $30 \mathrm{~cm}$ apart in the center of the box. The rats were tested $24 \mathrm{~h}$ after injection for their memory of a familiar object, as measured by the amount of time spent within one body length of a new object. The objects used on Day 1 were curved pieces of metal pipe open at one end. The novel object used was a plastic, T-shaped pipe open at both ends.

Habituation and training (Day 1). The rats were placed individually in the object recognition box without the objects in it and were allowed to explore for $2 \mathrm{~min}$. Twenty minutes later, the rats were placed in the object recognition box with the same two objects for $3 \mathrm{~min}$. There were no significant baseline differences among groups in open field behavior or in investigation of objects. Following training, the rats were injected with T, DHT, or $3 \alpha$-Diol $(0.0,3.0$, or $7.5 \mathrm{mg} / \mathrm{kg}$ ).

Testing (Day 2). The rats were placed in the box with one of the objects from Day 1 and one new object. Proximity to both objects was recorded for $3 \mathrm{~min}$.

One-way ANOVAs determined the effects of T, DHT, and $3 \alpha-$ Diol $(0.0,3.0$, and $7.5 \mathrm{mg} / \mathrm{kg})$ on time spent with the novel object (as a percentage of the total time spent with both objects).

Open field task. The open field task was used as a measure of anxiety and motor activity (Blizard, Lipman, \& Chen, 1975). The methods followed those described in McCarthy, Felzenberg, Robbins, Pfaff, and Schwartz-Giblin (1995). The open field was a box, $57 \mathrm{~cm}$ wide $\times 76 \mathrm{~cm}$ long, with a 48 -square grid floor $(6 \times 8$ squares, $9.5 \mathrm{~cm} /$ side) and a bright overhead light illuminating the central squares (all but the perimeter squares were considered central). The animals were injected with T, DHT, or $3 \alpha$-Diol $(0.0,3.0$, or $7.5 \mathrm{mg} /$ $\mathrm{kg} \mathrm{SC}$ ) and placed in the box and were observed for $5 \mathrm{~min}, 1$ and $24 \mathrm{~h}$ postinjection. The ratio of central squares entered to total number of entries into any square was used as an index of anxiety.

One-way ANOVAs followed by SNK post hocs examined the effects of T, DHT, and $3 \alpha$-Diol $(0.0,3.0$, and $7.5 \mathrm{mg} / \mathrm{kg})$ on the central versus total square entries ratio, 1 and $24 \mathrm{~h}$ postinjection.

Elevated plus maze task. The elevated plus maze paradigm described by Pellow and File (1986) and as per Dunn, Reed, Copeland, and Frye (1998) and Frye et al. (2000) was used to measure anxiety in the rats. The elevated plus maze consisted of four arms $10 \mathrm{~cm}$ wide elevated $50 \mathrm{~cm}$ off the ground. Two arms were enclosed by walls $30 \mathrm{~cm}$ high, and the other two arms were exposed. The maze was located in a brightly lit behavioral testing room. The rats were placed at the junction of the open and closed arms of the maze and were observed for $5 \mathrm{~min}$. An entry into the open arm was considered to be when all four paws of the animal were on the open arm. The amount of time spent on the open arms was recorded 1 and $24 \mathrm{~h}$ after injection of T, DHT, or $3 \alpha$-Diol $(0.0,3.0$, and $7.5 \mathrm{mg} / \mathrm{kg} \mathrm{SC})$.

One-way ANOVAs followed by SNK post hocs examined the effects of T, DHT, and $3 \alpha$-Diol $(0.0,3.0$, and $7.5 \mathrm{mg} / \mathrm{kg})$ on anxiety at 1 and $24 \mathrm{~h}$ postinjection, as measured by total percentage of time spent in the open arms during the 5-min test.

Tailflick. The tailflick paradigm used was described by D'Amour and Smith (1941) and was done according to the methods of Frye and Duncan $(1994,1996)$ to test the effects of T, DHT, and $3 \alpha$-Diol on pain sensitivity. The rats were handled, covered with a towel, placed on the platform of the tailflick apparatus (San Diego Instruments), and held in place as their tails were smoothed above the radiant heat source. The mean latency of three tailflick trials 1 and $24 \mathrm{~h}$ after T, DHT, and $3 \alpha$-Diol administration was used as an index of nociception. The stimulus intensity of the radiant heat source was set at the beginning of the experiments to produce control latencies between 2-3 sec. The maximum cut-off latency was $10 \mathrm{sec}$.

One-way ANOVAs examined differences on the latency measure between $0.0,3.0$, and $7.5 \mathrm{mg} / \mathrm{kg}$ at $1 \mathrm{~h}$ and at $24 \mathrm{~h}$ postinjection of T, DHT, or $3 \alpha$-Diol.

Steroid hormone measurements. Following behavioral testing, the rats were readministered their assigned milieu of T, DHT, 
or $3 \alpha$-Diol $(0.0,3.0$, or $7.5 \mathrm{mg} / \mathrm{kg})$, and blood was collected from the tail vein 1 and $24 \mathrm{~h}$ later. Plasma samples were extracted with diethyl ether, reconstituted in phosphate assay buffer $(\mathrm{ph}=7.4$ ), equilibrated, and analyzed by enzyme-linked immunosorbent assay (T: Oxford Biomedical Research EA78) or radioimmunoassay (DHT, Endocrine Sciences, DT3-351, 1:20,000 and 3 $\alpha$-Diol, Southwestern Foundation for Biomedical Research, X-144, 1:20,000; Frye, McCormick, Coopersmith, \& Erskine, 1996; Frye, van Keuran, Rao, \& Erskine, 1996b) to determine the circulating concentrations of the steroids administered.

\section{Results}

Y maze. Both dosages of $\mathrm{T}[F(2,21)=4.14, p<.05]$, DHT $[F(2,21)=4.42, p<.05]$, and $3 \alpha$-Diol $[F(2,21)=$ $12.30, p<.05]$ significantly increased the percentage of correct choices made in the Y maze more than did vehicle administration (see Figure 1).

Inhibitory avoidance. Both dosages of DHT $[F(2,21)$ $=4.48, p<.05]$ and $3 \alpha$-Diol $[F(2,21)=5.70, p<.01]$ significantly increased latencies to cross-over to the shockassociated, dark side of the inhibitory avoidance chamber compared with vehicle control administration. Although latencies were higher following $\mathrm{T}$, they did not reach statistical significance (Figure 2).

Object recognition. Both dosages of $\mathrm{T}[F(2,21)=$ $20.41, p<.01]$, DHT $[F(2,21)=3.44, p<.05]$, and $3 \alpha-$ Diol $[F(2,21)=3.844, p<.05]$ increased the percentage of time spent with a novel object compared with vehicle control administration (see Figure 3 ).

Open field. Both dosages of T $[F(2,21)=4.00, p<$ $.05]$, DHT $[F(2,21)=5.34, p<.01]$, and $3 \alpha$-Diol $[F(2,21)$ $=23.43, p<.01]$, when administered $1 \mathrm{~h}$ but not $24 \mathrm{~h}$ prior to testing, significantly increased the number of entries into the central squares compared with vehicle controls (see Figure 4).

Elevated plus maze. Both dosages of $\mathrm{T}[F(2,21)=$ $4.06, p<.05]$, DHT $[F(2,21)=4.01, p<.05]$, and $3 \alpha-$ $\operatorname{Diol}[F(2,21)=4.76, p<.05]$ caused the animals to spend a greater percentage of the test time in the open arms of the elevated plus maze $1 \mathrm{~h}$ postinjection than did vehicle control administration (see Figure 5). Effects of androgen administration were not apparent 24 -h postinjection and were comparable to vehicle control at that time.

Tailflick. Both dosages of T $[F(2,21)=7.61, p<.01]$, DHT $[F(2,21)=7.53, p<.01]$, and $3 \alpha$-Diol $[F(2,21)=$ $8.58, p<.05]$ increased latencies to tailflick at 1 -h postinjection compared with vehicle control (see Figure 6). The androgens did not significantly affect latencies to tailflick at 24-h postinjection and were not different from vehicle administration at this time.

Steroid hormone measurements. Testosterone concentrations following administration of 3.0 and $7.5 \mathrm{mg} / \mathrm{kg}$ were significantly increased over control $0.0 \mathrm{mg} / \mathrm{kg}$ values 1 but not $24 \mathrm{~h}$ later $[F(2,42)=34.68, p<.01]$. Testosterone concentrations $1 \mathrm{~h}$ following 3.0 or $7.5 \mathrm{mg} / \mathrm{kg}$ were $0.49 \pm 0.05$ and $0.72 \pm 0.08 \mathrm{ng} / \mathrm{ml} ; 24 \mathrm{~h}$ following $\mathrm{T}(3.0$ or $7.5 \mathrm{mg} / \mathrm{kg}$ ) and 1 or $24 \mathrm{~h}$ following vehicle controls, concentrations were $0.08 \pm 0.01 \mathrm{ng} / \mathrm{ml}$. Testosterone
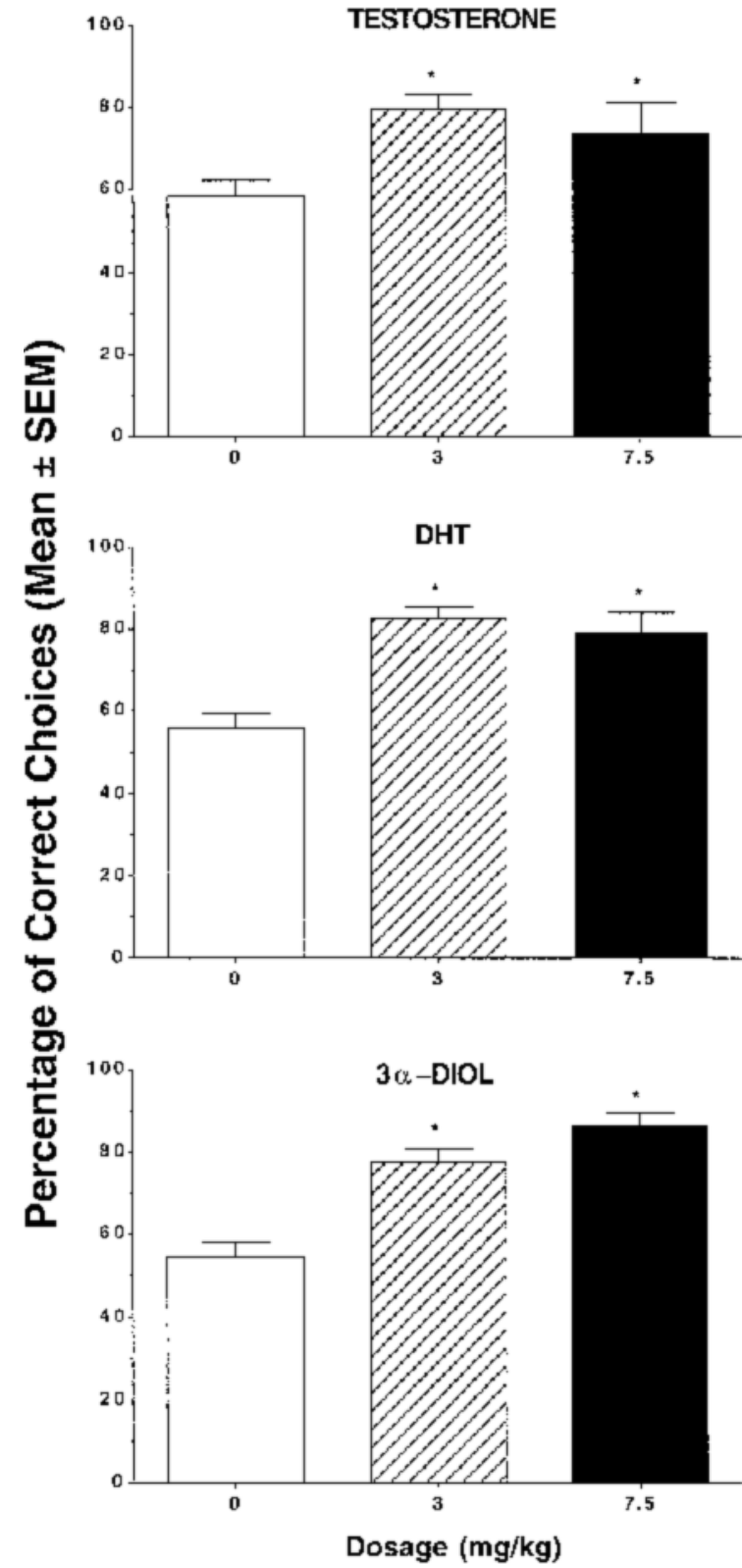

Figure 1. Overall percentage of correct choices $( \pm S E M)$ for $T$ (top), DHT (middle), and 3 $\alpha$-Diol (bottom) in the Y-maze. Both dosages $(3.0 \mathrm{mg} / \mathrm{kg}$ represented by striped bars and $7.5 \mathrm{mg} / \mathrm{kg}$ represented by solid bars) of T, DHT, and $3 \alpha$-Diol increased the percentage of correct choices in the $Y$ maze.

concentrations typically range from approximately $0.1 \mathrm{ng} /$ $\mathrm{ml}$ on diestrus to $0.6 \mathrm{ng} / \mathrm{ml}$ on proestrus (Belanger, $\mathrm{Cu}$ san, Barden, \& DuPont, 1981).

DHT concentrations following 3.0 and $7.5 \mathrm{mg} / \mathrm{kg}$ were significantly increased over control $0.0 \mathrm{mg} / \mathrm{kg}$ values 1 but not $24 \mathrm{~h}$ following administration $[F(2,42)=11.09$, $p<.01]$. DHT concentrations $1 \mathrm{~h}$ following 3.0 or $7.5 \mathrm{mg} /$ $\mathrm{kg}$ were $0.40 \pm 0.02$ and $0.59 \pm 0.01 \mathrm{ng} / \mathrm{ml} ; 24 \mathrm{~h}$ follow- 

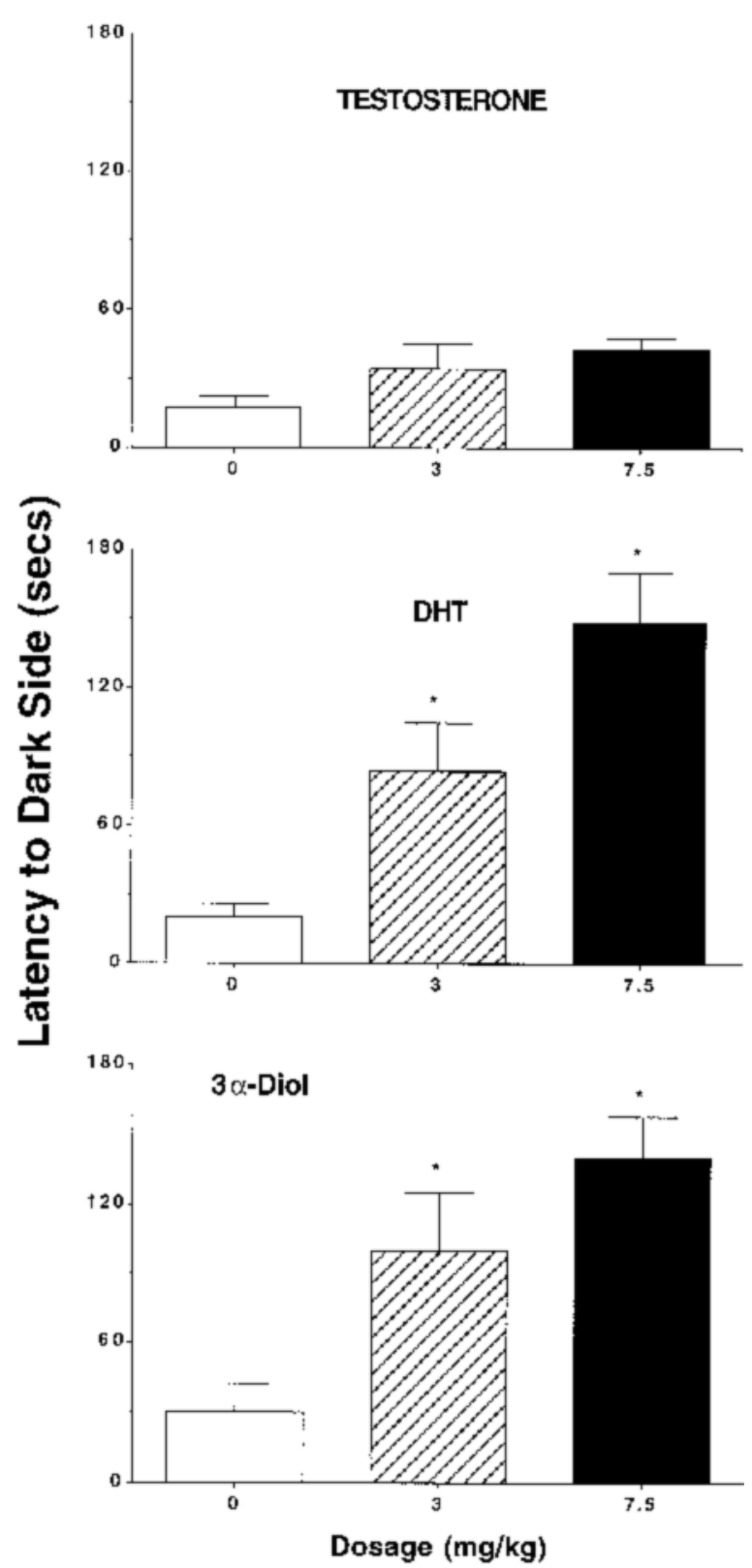

Figure 2. Latency to cross to the dark side $( \pm S E M)$ for $T$ (top), DHT (middle), and 3 $\alpha$-Diol (bottom). *Indicates that both dosages of DHT and $3 \alpha$-Diol $(3.0 \mathrm{mg} / \mathrm{kg}$ striped bars and $7.5 \mathrm{mg} / \mathrm{kg}$, solid bars) significantly increased latency to enter the dark, shockassociated side of the chamber. However, $T$ did not significantly increase latencies.

ing DHT administration (3.0 or $7.5 \mathrm{mg} / \mathrm{kg}$ ) and 1 or $24 \mathrm{~h}$ following vehicle control administration, concentrations were $0.17 \pm 0.07 \mathrm{ng} / \mathrm{ml}$. Diestrus DHT concentrations typically range from approximately $0.4 \mathrm{ng} / \mathrm{ml}$ on diestrus to $0.8 \mathrm{ng} / \mathrm{ml}$ on proestrus (Belanger et al., 1981).

Concentrations of $3 \alpha$-Diol following administrations of 3.0 and $7.5 \mathrm{mg} / \mathrm{kg}$ were significantly increased over control $0.0 \mathrm{mg} / \mathrm{kg}$ values 1 but not $24 \mathrm{~h}$ following $3 \alpha$-Diol $[F(2,42)=6.19, p<.01]$. Concentrations of $3 \alpha$-Diol $1 \mathrm{~h}$ following administration of 3.0 or $7.5 \mathrm{mg} / \mathrm{kg}$ were $3.1 \pm$ 0.2 and $3.9 \pm 0.4 \mathrm{ng} / \mathrm{ml} ; 24 \mathrm{~h}$ following $3 \alpha$-Diol (3.0 or $7.5 \mathrm{mg} / \mathrm{kg}$ ) administration and 1 or $24 \mathrm{~h}$ following vehicle control administration, concentrations were $1.9 \pm 0.3$ $\mathrm{ng} / \mathrm{ml}$. Diestrus $3 \alpha$-Diol concentrations typically range from approximately $1.2 \mathrm{ng} / \mathrm{ml}$ on diestrus to $0.8-7.0 \mathrm{ng} / \mathrm{ml}$ on proestrus (Meijs-Roelofs, Kramer, Gribling-Hegge, \& Woutersen, 1986; Meijs-Roelofs, Kramer, van Cappellen, \& Woutersen, 1985).

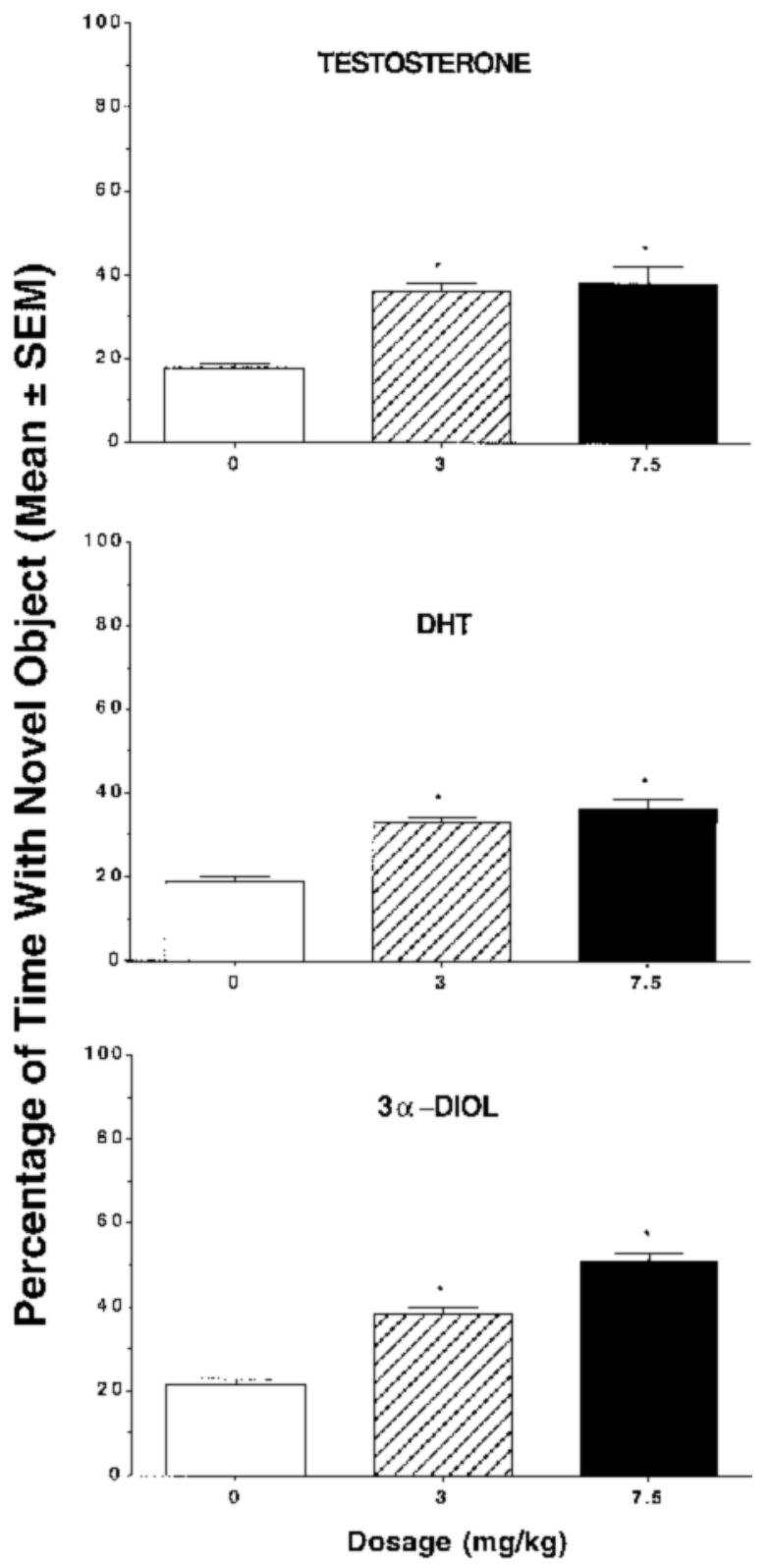

Figure 3. Percentage of time spent with a novel object $( \pm S E M)$ for T (top), DHT (middle), and 3 $\alpha$-Diol (bottom). * Indicates that both dosages $(3.0 \mathrm{mg} / \mathrm{kg}$ striped bars and $7.5 \mathrm{mg} / \mathrm{kg}$, solid bars) of T, DHT and $3 \alpha$-Diol significantly increased the percentage of time investigating a novel object. 


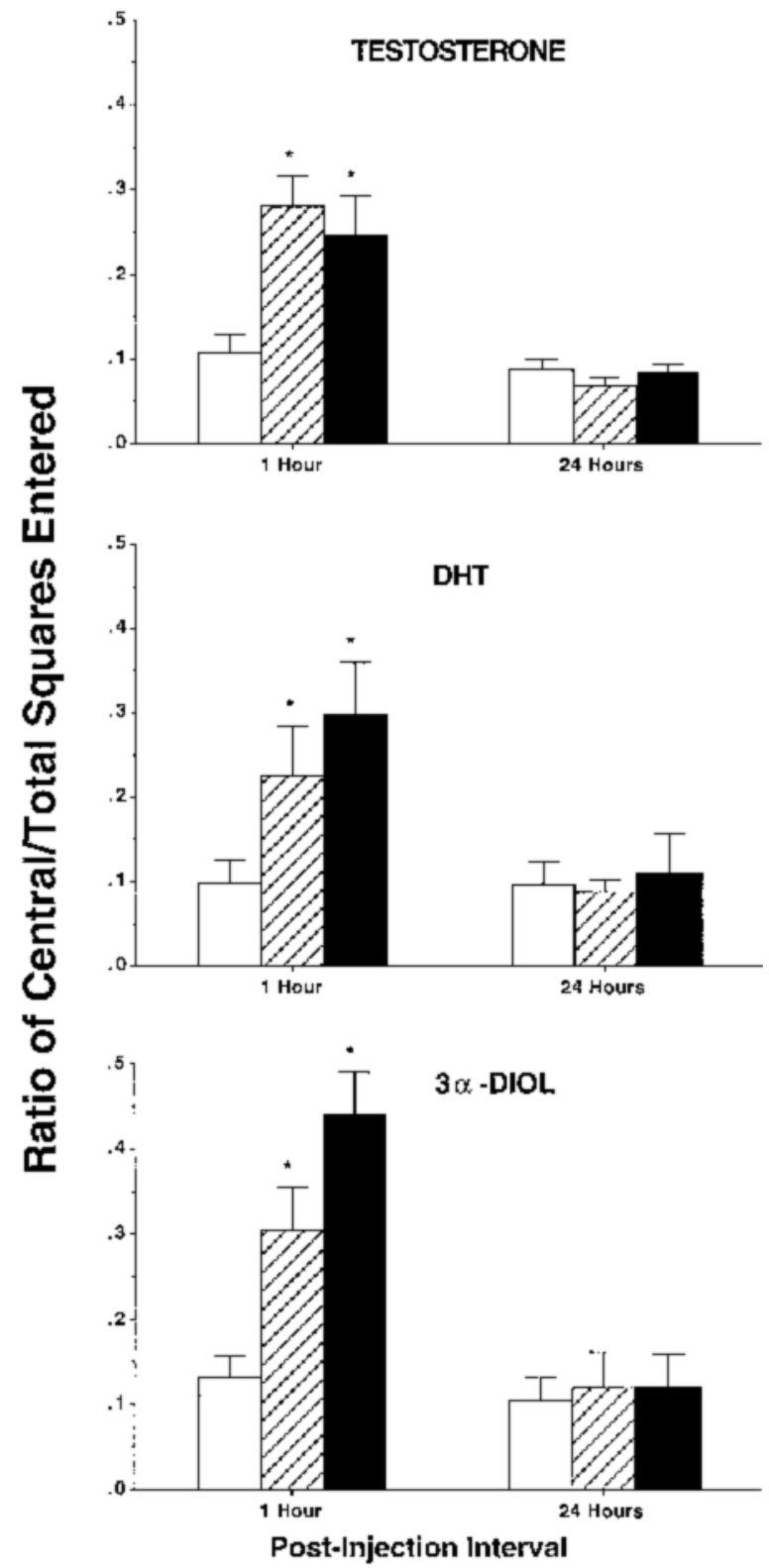

Figure 4. Ratio of central to total squares entered in the open field $( \pm S E M) 1$ and $24 \mathrm{~h}$ following T (top), DHT (middle), or $3 \alpha$ Diol (bottom). *Indicates both dosages $(3.0 \mathrm{mg} / \mathrm{kg}$, striped bars and $7.5 \mathrm{mg} / \mathrm{kg}$, solid bars) of T, DHT, and $3 \alpha$-Diol caused rats to enter more central squares $1 \mathrm{~h}$ after injection than did vehicle administration. At $24 \mathrm{~h}$ following administration, there were no differences between the dosages for any of the androgens.

\section{DISCUSSION}

The present experiment was consistent with the hypothesis that posttraining androgens enhance consolidation, and therefore, performance on some cognitive tasks $24 \mathrm{~h}$ following administration, when plasma androgen levels were no longer elevated. Posttraining administration of T, DHT, and $3 \alpha$-Diol, which produced physiological concentrations of androgens $1 \mathrm{~h}$ following administra- tion but not $24 \mathrm{~h}$ later at test time, increased the percentage of correct choices in the Y maze, enhanced crossover latencies to the shock-associated chamber in the inhibitory avoidance task, and increased the percentage of time exploring a novel object. The increase in entries into the center of the brightly lit open field, time spent on the open arms, and tailflick latencies were observed 1 but

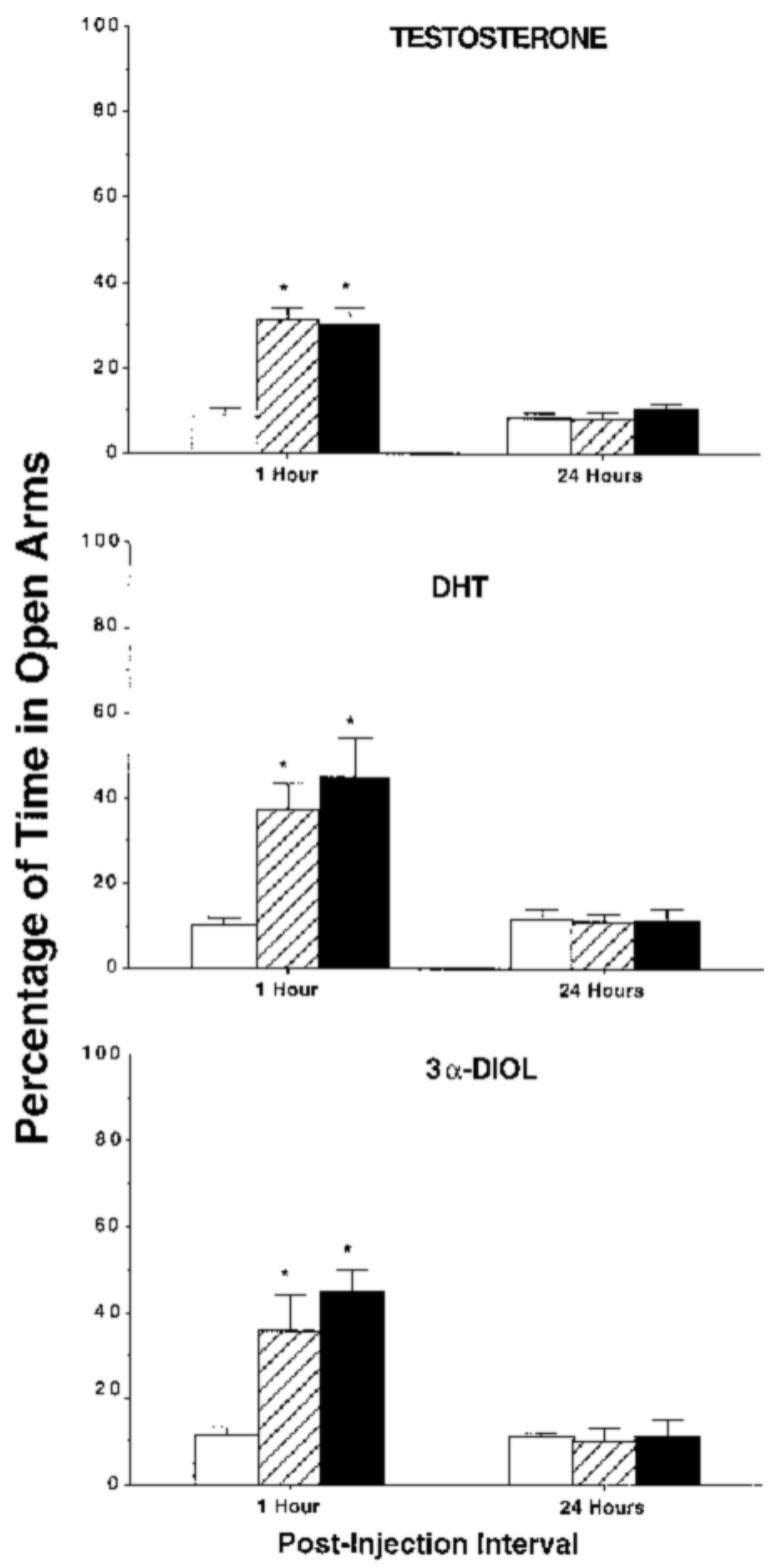

Figure 5. Percentage of time spent in the open arm of the elevated plus maze $( \pm S E M)$ following $T$ (top), DHT (middle), and $3 \alpha$-Diol (bottom). Open bars represent effects of vehicle administration, striped bars represent administration of $3.0 \mathrm{mg} / \mathrm{kg}$ androgen, and solid bars show effects of $7.5 \mathrm{mg} / \mathrm{kg} \mathrm{of} \mathrm{T,} \mathrm{DHT,} \mathrm{and}$ 3 $\alpha$-Diol. *Indicates that $1 \mathrm{~h}$ following 3.0 or $7.5 \mathrm{mg} / \mathrm{kg}$ of T, DHT, or $3 \alpha$-Diol, open arm time was significantly increased compared to that seen following vehicle administration. Twenty-four hours following androgen administration open arm time was no different from vehicle administration. 


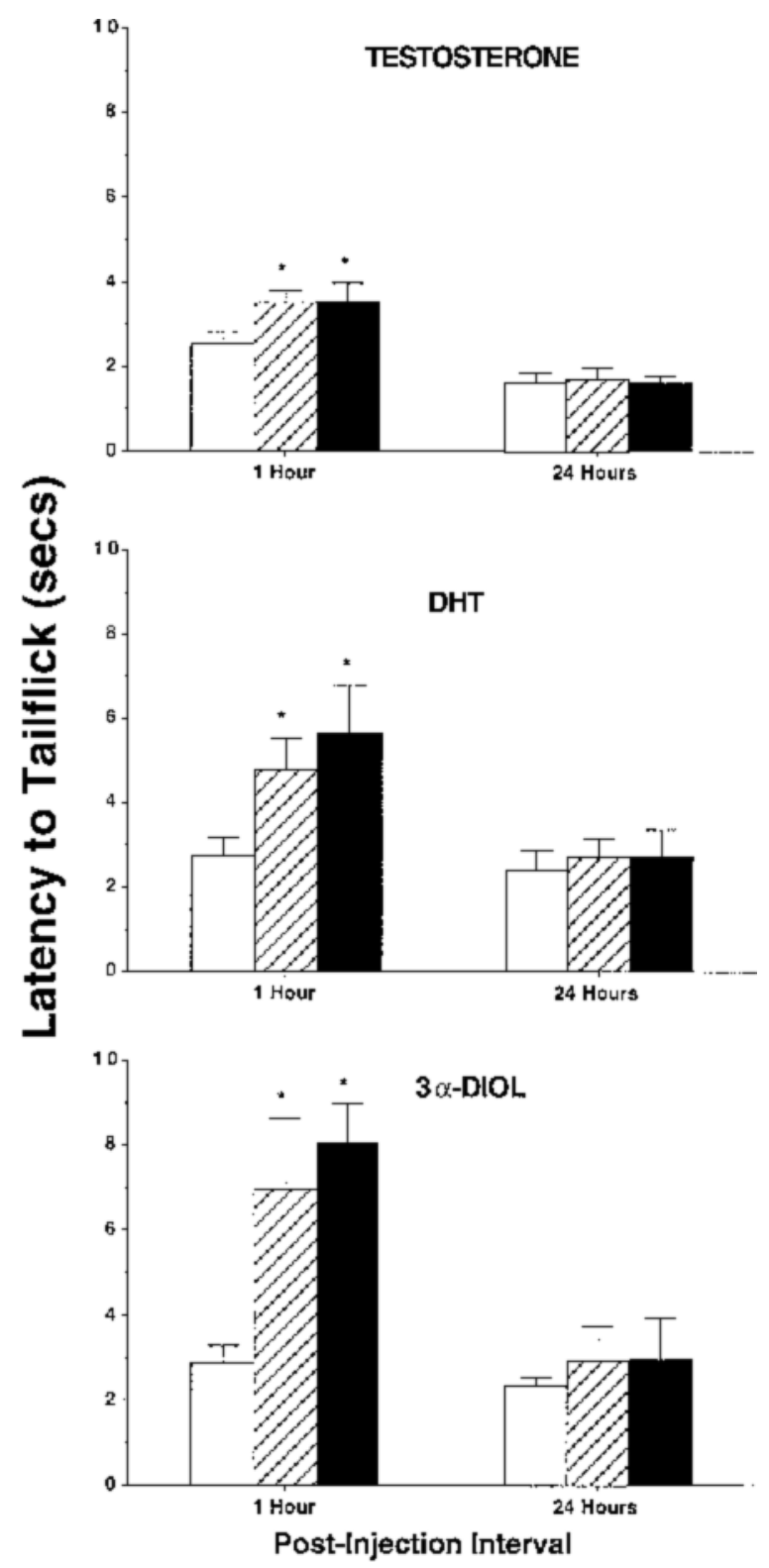

Figure 6. Latency to flick tail from a heat source $( \pm S E M) 1$ and $24 \mathrm{~h}$ following T (top), DHT (middle), or $3 \alpha$-Diol (bottom). Both dosage $(3.0 \mathrm{mg} / \mathrm{kg}$, striped bars and $7.5 \mathrm{mg} / \mathrm{kg}$, solid bars) of $\mathrm{T}$, DHT, and $3 \alpha$-Diol increased the latency to tailflick $1 \mathrm{~h}$ after injection. *Indicates that $1 \mathrm{~h}$ following 3.0 or $7.5 \mathrm{mg} / \mathrm{kg}$ of T, DHT, or $3 \alpha$-Diol, tailflick latencies were significantly increased compared to that seen following vehicle administration. Twenty-four hours following and rogen administration tailflick latencies were no different from vehicle administration.

not $24 \mathrm{~h}$ following androgen administration. No overt changes in these "affective behaviors" were seen $24 \mathrm{~h}$ following androgen administration, yet changes in cognitive performance were observed at this time. Together, these data suggest that posttraining androgens can enhance learning and memory through consolidation and that these effects on cognitive performance are not due to androgens' producing changes in affective behavior.
The present finding that androgens can have activational effects that enhance cognitive task performance when administered posttraining in the dosages utilized here are congruous with previous data that have shown that androgen levels in adulthood are related to performance on spatial tasks (Almeida, 1999; Christiansen \& Knussmann, 1987; Gouchie \& Kimura, 1991; Janowsky, Oviatt, \& Orwoll, 1994; McKeever \& Deyo, 1990; Postma et al., 2000; Silverman, Kastuk, Choi, \& Phillips, 1999; van Goozen, Cohen-Kettenis, Gooren, Frijda, \& van de Poll, 1994). Some studies have failed to show a relationship between androgens and spatial performance (Hassler, 1992). However, the lack of effect in those studies may be due to the curvilinear relationship between androgens and spatial ability (Gouchie \& Kimura, 1991; McKeever, Rich, Deyo, \& Conner, 1987). For example, women with higher $\mathrm{T}$ concentrations perform better on spatial tasks than do women with low T (Gouchie \& Kimura, 1991; Sherwin, 1988a, 1988b), whereas men with low T perform better on some cognitive tasks than men with high $\mathrm{T}$. Testosterone replacement in men has been found to improve performance on a spatial block design test (Smith, Jonides, \& Koeppe, 1996). The present findings that T, DHT, and $3 \alpha$-Diol enhance cognitive performance concur with past research, particularly that which shows that $\mathrm{T}$ increases visuospatial ability in mice (Sih et al., 1997) and short-term memory in rats (Vazquez-Pereyra, Rivas-Arancibia,Loaeza-Del Castillo, \& Schneider-Rivas, 1995). Although passive avoidance performance tends to be unaffected by T (Banfi, Cornelli, Fonio, \& Dorigotti, 1982) cross-over latencies in this task were increased by $3 \alpha$-Diol administration in the present experiments and in a previous study (Frye \& McCormick, 2000).

The fact that posttraining T, DHT, and $3 \alpha$-Diol have effects on cognitive performance and that these androgens can also alter affect extends the literature on androgens and cognitive ability in several important ways. First, androgens seemed to have improved performance by enhancing consolidation. Androgens were administered after training and, $1 \mathrm{~h}$ later, circulating concentrations of androgens were at physiological levels. Circulating concentrations had returned to baseline control levels $24 \mathrm{~h}$ later (at the time of cognitive testing), which clearly suggests that androgens enhance consolidation. Second, androgens also seemed to have had some effect on acquisition. In the inhibitory avoidance and object recognition tasks, information is acquired during pretraining that must be remembered during the testing phase, after androgen administration. However, for the Y maze, no information presented during pretraining was to be remembered during testing other than the general rules of alternation. What was being tested in the Y maze was the ability both to employ the rule of alternation that had been previously trained and to recall and employ the information regarding which arm was just visited. Since the percentage of correct choices was enhanced by androgen administration, this suggests the posttraining presence of androgens may have enhanced both consolidation of the alternation rule and acquisition of the trial-by-trial information on 
test days. Thus, androgens' effects on both acquisition and consolidation were demonstrated in the Y-maze task. Third, in the present study, posttraining androgens enhanced both spatial (Y-maze performance) and nonspatial (object recognition and inhibitory avoidance task performance) memory. These findings are congruous with previous studies that have demonstrated that estradiol, given immediately posttraining, enhances consolidation in a spatial water maze task (Packard, 1998; Packard \& Teather, 1997a, 1997b) and extend them to suggest that androgens can also enhance consolidation of spatial and nonspatial information.

There is some evidence in the literature that androgens can be anxiolytic, and the present findings reinforce that notion and suggest that androgens may have similar mechanisms but different time courses for influencing affective and cognitive behavior. First, T (Forman, Tingle, Estilow, \& Cater, 1945) and $3 \alpha$-Diol (Frye et al., 1996a) can reduce pain (Klimek, 1985) and produce analgesia in rats. Androgen treatment reduces fear reactions to unfamiliar stimuli in ewes and heifers (Boissy \& Bouissou, 1994; Vandenheede \& Bouissou, 1993). Chronic administration of testosterone proprionate, which produced 10fold increases in circulating androgens, produced antianxiety performance in the plus maze (Bitran, Kellogg, $\&$ Hilvers, 1993), which may be related to $3 \alpha$-Diol's or to androsterone's potent stimulatory effects on GABA activity (Bitran, Hilvers, Frye, \& Erskine, 1996). Second, in the present experiment, it is unlikely that the aforementioned analgesic or anxiolytic effects of androgens directly influenced performance on cognitive tasks. The changes in affective behaviors were apparent $1 \mathrm{~h}$ but not $24 \mathrm{~h}$ following androgen administration, which coincides, respectively, with elevated and basal circulating concentrations of androgens. Notably, the effects of androgens $24 \mathrm{~h}$ later on affective tasks were not test decay effects, as individuals in each group were counterbalanced so that some subjects were initially tested in the affective tests $24 \mathrm{~h}$ following androgen administration, and others were tested initially $1 \mathrm{~h}$ following androgen administration. Third, in addition to the previous and present data that androgens can influence spatial and nonspatial memory and affect, there are also reports that $\mathrm{T}$ and its $5 \alpha$ reduced metabolites can produce positive reinforcing effects. Systemic and intranucleus accumbens administration of T (Alexander, Packard, \& Hines, 1994; Packard, Cornell, \& Alexander, 1997) and its $5 \alpha$-reduced metabolites (Frye, Park, Tanaka, Rosellini, \& Svare, in press) enhance conditioned place preference, suggesting that these androgens can produce positive hedonic effects and enhance learning and memory function. Finally, in some people, the abuse liability of androgens may be associated with their ability to produce well-remembered, positive hedonic effects (Fingerhood, Sullivan, Testa, \& Jasinski, 1997).

The present findings showing androgens' cognitive and anxiolytic effects produced by T, DHT, and $3 \alpha$-Diol were similar, suggesting that the mechanism of the an- drogens' actions to produce these effects may be similar. Traditionally, androgens, such as T and DHT, are thought to produce their effects by influencing neuronal function by binding to intracellular receptors that can act as transcription factors and regulate gene expression. In addition, neurosteroids, such as $3 \alpha$-Diol, are potent modulators of ligand-gated ion channels, such as $\mathrm{GABA}_{\mathrm{A}}$ /benzodiazepine receptor complexes (GBRs). Both T and DHT have high affinities for intracellular androgen receptors, but $3 \alpha$-Diol is devoid of activity at intracellular androgen receptors (Roselli, 1991). The opposite is true of androgens' effects at GBRs; $3 \alpha$-diol has high activity at GBRs, but T and DHT are only weakly active (Gee, 1988). However, some of T's and DHT's behavioral effects have been attributed to their metabolism to $3 \alpha$-Diol (Erskine, 1989; Erskine et al., 1992; Frye \& Reed, 1998), which acts at GBRs (Frye, Duncan, et al., 1996; Frye, van Keuran, \& Erskine, 1996; Frye et al., 1996b) rather than at intracellular androgen receptors. Testosterone is readily metabolized to DHT and $3 \alpha$-Diol (Martini, 1982). The similar cognitive and anxiolytic-like effects of both dosages of T, DHT, and $3 \alpha$-Diol, despite their discrepant actions at intracellular androgens receptors and GBRs, suggest that the present actions of T and DHT may have been due to their metabolism to $3 \alpha$-Diol and subsequent actions at GBRs. Notably, the circulating concentrations of $3 \alpha$-Diol produced by the $3.5 \mathrm{mg} / \mathrm{kg}$ dosages of $\mathrm{T}$, DHT, and $3 \alpha$-Diol would be sufficient to increase GBR function (Gee, 1988). Additional evidence for T's, DHT's, and $3 \alpha$-Diol's present effects' being through GBRs rather than through intracellular receptors include the fact that these androgens all similarly enhance conditioned place preference when applied to the nucleus accumbens, an area of the brain lacking in intracellular androgen receptors (Frye, Rhodes, Rosellini, \& Svare, 2001) but containing the $5 \alpha$-reductase enzyme and GBRs.

Are the present effects of androgens a result of aromatization to estradiol? Testosterone can be aromatized to E, which has been clearly demonstrated to improve cognition. However, DHT's and $3 \alpha$-Diol are not metabolized to E. Hence, conversion to E cannot explain DHT and $3 \alpha$-Diol's effects on cognitive and affective behaviors. Perhaps the lack of effect of $\mathrm{T}$ in the inhibitory avoidance tasks in the present and past experiments are due to T's being converted to $\mathrm{E}$ and its producing subthreshold levels of both T $5 \alpha$-reduced metabolites and $\mathrm{E}$, the aromatized metabolite. Previous literature indicates that $\mathrm{E}$ can enhance cognitive performance, and the present results suggest that $5 \alpha$-reduced androgens can enhance spatial and nonspatial ability. Together, this suggests that T's two metabolism pathways, both aromatization to estradiol and $5 \alpha$-reduction to DHT, and $3 \alpha$-Diol may yield products that each have memory enhancing and affect changing influences.

In summary, posttraining administration of T, DHT, and $3 \alpha$-Diol improved performance in the Y maze, inhibitory avoidance, and object recognition tasks above that seen with vehicle control administration. The effects of these 
androgens on cognitive performance were temporally distinct from T's, DHT's, and $3 \alpha$-Diol's enhancement of open field, elevated plus maze, and tailflick latencies. Thus, the present study demonstrates that the improvement in cognitive performance induced by these androgens were not due to overt changes in the affective behaviors examined. Since androgen levels were increased 1 but not $24 \mathrm{~h}$ later at test time, this suggests that improvements in performance on the cognitive tasks may then be due to enhanced consolidation and acquisition of short- and long-term memory tasks. Further, investigation of androgens' effects on cognition and affect are particularly important. Although the effects of androgens on memory and affect were more modest than those seen with other drugs that may have similar actions (e.g., benzodiazepines), androgens effects are worthy of further investigation because of reports indicating that testosterone can improve spatial cognition and working memory in people (Janowsky, Chavez, \& Orwoll, 2000; Janowsky et al., 1994).

\section{REFERENCES}

Aggleton, J. P., Hunt, P. R., \& Rawlins, J. N. P. (1989). Effects of amygdaloid and amygdaloid-hippocampal lesions on object recognition and spatial working memory in rats. Behavioral Neuroscience, 103, 962-974.

Alexander, G., Packard, M., \& Hines, M. (1994). Testosterone has rewarding affective properties in male rats: Implications for the biological basis of sexual motivation. Behavioral Neuroscience, 108, 424-428.

Almeida, O. P. (1999). Sex playing with the mind: Effects of oestrogen and testosterone on mood and cognition. Arquivos de Neuro-psiquiatria, 57, 701-706

Banfi, S., Cornelli, U., Fonio, W., \& Dorigotti, L. (1982). A screening method for substances potentially active on learning and memory. Journal of Pharmacology Methods, 8, 255-263.

BEATTY, W. W. (1984). Hormonal organization of sex differences in play fighting and spatial behavior. Progress in Brain Research, 61, 315-330.

Belanger, A., Cusan, L., Barden, L., \& Dupont, A. (1981). Ovarian progestins, androgens and estrogen throughout the 4-day estrous cycle in the rat. Biology of Reproduction, 24, 591-596.

Berry, B., McMahan, R., \& Gallagher, M. (1997). Spatial learning and memory at defined points of the estrous cycle: Effects on performance of a hippocampal-dependent task. Behavioral Neuroscience, 111, 267-274.

Bitran, D., Hilvers, R. J., Frye, C. A., \& Erskine, M. S. (1996). Chronic anabolic-androgenic steroid treatment affects brain GABA $_{\mathrm{A}}$ receptor-gated chloride ion transport. Life Sciences, 58, 573-583.

Bitran, D., KellogG, C. K., \& Hilvers, R. J. (1993). Treatment with anabolic-androgenic steroid affects anxiety-related behavior and alters the sensitivity of cortical GABA A $_{\mathrm{A}}$ receptors. Hormones \& Behavior, 27, 568-583.

Blizard, D. A., Lipman, H. R., \& Chen, J. J. (1975). Sex differences in open-field behavior in the rat: The inductive and activational role of gonadal hormones. Physiology \& Behavior, 14, 601-608.

Boissy, A., \& Bouissou, M. F. (1994). Effects of androgen treatment on behavioral and physiological responses of heifers to fear-eliciting situations. Hormones \& Behavior, 28, 66-83.

Christiansen, K., \& Knussmann, R. (1987). Androgen levels and components of aggressive behavior in men. Hormones \& Behavior, 21, 170-180.

D’ Amour, F. E., \& Sмiтh, D. L. (1941). A method for determining loss of pain sensation. Journal of Pharmacology \& Experimental Therapy, 72, 74-79.

Daniel, J. M., Fader, A. J., Spencer, A. L., \& Dohanich, G. P. (1997).
Estrogen enhances performance of female rats during acquisition of a radial arm maze. Hormones \& Behavior, 32, 217-225.

Daniel, J. M., Roberts, S. L., \& Dohanich, G. P. (1999). Effects of ovarian hormones and environment on radial maze and water maze performance of female rats. Physiology \& Behavior, 66, 11-20.

Dawson, J. L. M. (1972). Effects of sex hormones on cognitive style in rats and men. Behavior: General, 2, 21-42.

Dunn, R. W., Reed, T. A. W., Copeland, P. D., \& Frye, C. A. (1998). The nitric oxide synthase inhibitor 7-nitroindazole displays enhanced anxiolytic eff icacy without tolerance in rats following subchronic administration. Neuropharmacology, 37, 899-904.

ERSKINE, M. S. (1989). Effect of $5 \alpha$-dihydrotestosterone and flutamide on the facilitation of lordosis by LHRH and naloxone in estrogenprimed female rats. Physiology \& Behavior, 43, 753-759.

ERSKIne, M. S., HipPensteIL, M., \& Kornberg,E. (1992). Metabolism of dihydrotestosterone to $3 \alpha$-androstanediol in brain and plasma: Effect on behavioral activity in female rats. Journal of Endocrinology, 134, 183-195.

Fingerhood, M. I., Sullivan, J. T., Testa, M., \& Jasinski, D. R. (1997). Abuse liability of testosterone. Journal of Psychopharmacology, 11, 59-63.

Forman, L. J., Tingle, V., Estilow, S., \& Cater, J. (1945). The response to analgesia testing is affected by gonadal steroids in the rat. Life Sciences, 45, 447-454.

FrYe, C. A. (1995). Estrus-associated decrements in water maze task are limited to acquisition. Physiology \& Behavior, 57, 5-14.

FRYE, C. A. (2001). Estradiol prevents inhibitory avoidance deficits and pyknotic cells in the granule layer of the dentate gyrus induced by adrenalectomy in rats. Brain Research, 889, 358-363.

Frye, C. A., Bock, B. C., \& Kanarek, R. B. (1992). Hormonal milieu affects tailflick latency in female rats and may be attenuated by access to sucrose. Physiology \& Behavior, 52, 699-706.

Frye, C. A., \& Duncan, J. E. (1994). Progesterone metabolites, effective at the $\mathrm{GABA}_{\mathrm{A}}$ receptor complex, attenuate pain sensitivity in rats. Brain Research, 643, 194-203.

Frye, C. A., \& Duncan, J. E. (1996). Estradiol benzoate potentiates neuroactive steroids' effects on pain sensitivity. Pharmacology, Biochemistry \& Behavior, 53, 27-32.

Frye, C. A., Duncan, J. E., Basham, M., \& Erskine, M. S. (1996). Behavioral effects of $3 \alpha$-androstanediol II: Hypothalamic and preoptic area actions via a GABAergic mechanism. Behavioural Brain Research, 79, 119-130.

Frye, C. A., \& LAcey, E. H. (1999). The neurosteroids DHEA and DHEAS may influence cognitive performance by altering affective state. Physiology \& Behavior, 66, 85-92.

Frye, C. A., \& LACEy, E. H. (2000). Progestins influence performance on cognitive tasks independent of changes in affective behavior. Psychobiology, 28, 550-563.

Frye, C. A., \& McCormick, C. M. (2000). The neurosteroid $3 \alpha$ Androstanediol prevents inhibitory avoidance deficits and pyknotic cells in the granule layer of the dentate gyrus induced by adrenalectomy in rats. Brain Research, 855, 166-170.

Frye, C. A., McCormick, C. M., Coopersmith, C., \& Erskine, M. S. (1996). Effects of paced and non-paced mating stimulation on plasma progesterone, $3 \alpha$-Diol and corticosterone. Psychoneuroendocrinology, 21, 431-439.

Frye, C. A., Park, D., Tanaka, M., Rosellini, R., \& Svare, B. (in press). $3 \alpha$-androstanediol conditions a place preference. Psychoneuroendocrinology.

Frye, C. A., Petralia, S. M., \& Rhodes, M. E. (2000). Estrous cycle and sex differences in performance on anxiety tasks coincide with increases in hippocampal progesterone and $3 \alpha, 5 \alpha$-THP. Pharmacology, Biochemistry \& Behavior, 67, 1-10.

Frye, C. A., \& ReED, T. A. W. (1998). Androgenic neurosteroids: Antiseizure effects in an animal model of epilepsy. Psychoneuroendocrinology, 23, 385-399.

Frye, C. A., Rhodes, M. E., Rosellini, R, \& Svare, B. (2001). The testosterone metabolite $3 \alpha$-androstanediolmay mediate the effects of testosterone on conditioned place preference through actions in the nucleus accumbens. Manuscript submitted for publication.

Frye, C. A., \& Sturgis, J. D. (1995). Neurosteroids affect spatial/ref- 
erence, working and long-term memory of female rats. Behavioral \& Neural Biology, 64, 83-96.

Frye, C. A., van Keuran, K. R., \& Erskine, M. S. (1996). Behavioral effects of $3 \alpha$-androstanediol: I. Modulation of sexual receptivity and promotion of GABA-stimulated chloride flux. Behavioural Brain Research, 79, 109-118.

Frye, C. A., van Keuran, K. R., Rao, P. N., \& Erskine, M. S. (1996a). Analgesic effects of the neurosteroid $3 \alpha$-androstanediol. Brain Research, 709, 1-9.

Frye, C. A., van Keuran, K. R., Rao, P. N., \& Erskine, M. S. (1996b). Progesterone and $3 \alpha$-androstanediol conjugated to bovine serum albumin affects estrous behavior when applied to the MBH and POA. Behavioral Neuroscience, 110, 603-612.

Fugger, H. N., Cunningham, S. G., Rissman, E. F., \& Foster, T. C. (1998). Sex differences in the activational effects of $\operatorname{Er} \alpha$ on spatial learning. Hormones \& Behavior, 34, 163-170.

Galea, L. A. M., Kavaliers, M., Ossenkopp, K.-P., \& Hampson, E. (1995). Gonadal hormone levels and spatial learning performance in the Morris water maze in male and female meadow voles, Microtus pennsylvanicus. Hormones \& Behavior, 29, 106-125.

Gaulin, S. J. C., \& Fitzgerald, R. W. (1989). Sexual selection for spatiallearning ability. Animal Behaviour, 37, 322-331.

GEE, K. W. (1988). Steroid modulation of the GABA/benzodiazepine receptor-linked chloride ionophore. Molecular Neurobiology, 2, 291-317.

Gouchie, C., \& Kimura, D. (1991). The relationship between testosterone levels and cognitive ability patterns. Psychoneuroendocrinology, 16, 323-334.

Hassler, M. (1992). Creative musical behavior and sex hormones: Musical talent and spatial ability in the 2 sexes. Psychoneuroendocrinology, 17, 55-70

Isgor, C., \& Sengelaub,D. R. (1998). Prenatal gonadal steroids affect spatial behavior, CA1 and CA3 pyramidal cell morphology in rats. Hormones \& Behavior, 34, 183-198.

Janowsky, J. S., Chavez, B., \& Orwoll, E. S. (2000). Sex steroids modify working memory. Journal of Cognitive Neuroscience, 12 , 407-414.

JANOWSKy, J. S., Oviatt, S. K., \& ORwoll, E. S. (1994). Testosterone influences spatial cognition in older men. Behavioral Neuroscience, 108, 325-332.

Joseph, R., Hess, S., \& Birecree, E. (1978). Effect of hormone manipulations and exploration on sex differences in maze learning. $B e$ havioral Biology, 24, 364-377.

Kelsey, J. E., Sanderson, K. L., \& Frye, C. A. (2000). Perforant path stimulation produces seizures, loss of hippocampal neurons, and a deficit in spatial mapping in rats which is reduced by prior MK-801. Behavioural Brain Research, 107, 59-69.

KLIMEK, A. (1985). Use of testosterone in the treatment of cluster headache. European Journal of Neurology, 24, 53-56.

LuINE, V. N. (1997). Steroid hormone modulation of hippocampal dependent spatial memory. Stress, 2, 21-36.

Luine, V. N., Richards, S. T., Wu, V. Y., \& Beck, K. D. (1998). Estradiol enhances learning and memory in a spatial memory task and effects levels of monoaminergic neurotransmitters. Hormones \& $\mathrm{Be}$ havior, 34, 149-162.

LuINE, V. [N.], \& RodRiguez, M. (1994). Effects of estradiol on radial arm maze performance of young and aged rats. Behavioral \& Neural Biology, 62, 230-236.

Maren, S., De Oca, B., \& Fanselow, M. S. (1994). Sex differences in hippocampal and long-term potentiation (LTP) and Pavlovian fear conditioning in rats: Positive correlation between LTP and contextual learning. Brain Research, 661, 25-34.

Markus, E. J., \& ZeCEVIC,M. (1997). Sex differences and estrous cycle changes in hippocampus-dependent fear conditioning. Psychobiology, 25, 246-252.

MARTINI, L. (1982). The $5 \alpha$-reduction of testosterone in the neuroendocrine structures. Biochemical and physiological implications. Endocrine Reviews, 3, 1-25.

McCarthy, M. M., Felzenberg, E., Robbins, A., Pfaff, D. W., \& SchwartZ-Giblin, S. (1995). Infusions of diazepam and allopregna- nolone into the midbrain central gray facilitate open-field behavior and sexual receptivity in female rats. Hormones \& Behavior, 29, 279-295.

McCormick, C. M., McNamara, M., Mukhopadhyay, S., \& Kelsey, J. E. (1997). Acute corticosterone replacement reinstates performance on spatial and nonspatial memory tasks 3 months after adrenalectomy despite degeneration in the dentate gyrus. Behavioral Neuroscience, 111, 518-531.

McKeever, W.F., \& Deyo, R. A. (1990). Testosterone, dihydrotestosterone, and spatial task performance of males. Bulletin of the Psychonomic Society, 28, 305-308.

McKeever, W. F., Rich, D. A., Deyo, R. A., \& Conner, R. L. (1987). Androgens and spatial ability: Failure to find a relationship between testosterone and ability measures. Bulletin of the Psychonomic Society, 25, 438-440.

Meiss-Roelofs, H.M.A., Kramer, P., Gribling-Hegge, L., \& WouTERSEN, P. J. A. (1986). Periovulatory changes in serum concentration and of $5 \alpha$-androstane- $3 \alpha, 17 \beta$-diol in the androgenized rat. Biology of Reproduction, 35, 890-896.

Meijs-Roelofs, H. M. A., Kramer, P., van Cappellen, W. A., \& Woutersen, P. J. A. (1985). Changes in serum concentration and ovarian content of 5 -androstane- $3 \alpha, 17 \beta$-diol in the female rat approaching first ovulation. Biology of Reproduction, 32, 301-308.

O'Connell, A., Earley, B., \& Leonard, B. E. (1994). Phencyclidine prevents spatial navigation and passive avoidance deficits in ibotenate lesioned rats. Neuropharmacology, 33, 1095-1101.

PACKARD, M. G. (1998). Posttraining estrogen and memory modulation. Hormones \& Behavior, 34, 126-139.

Packard, M. G., Cornell, A. H., \& Alexander, G. M. (1997). Rewarding affective properties of intra-nucleus accumbens injections of testosterone. Behavioral Neuroscience, 111, 219-224.

Packard, M. G., \& Teather, L. A. (1997a). Intra-hippocampal estradiol infusion enhances memory in ovariectomized rats. NeuroReport, 8, 3009-3013

Packard, M. G., \& Teather, L. A. (1997b). Post-training estradiol injections enhance memory in ovariectomized rats: Cholinergic blockade and synergism. Neurobiology of Learning \& Memory, 68, 172-188.

Pellow, S., \& File, S. E. (1986). Anxiolytic and anxiogenic drug effects on exploratory activity in an elevated plus-maze: A novel test of anxiety in the rat. Pharmacology, Biochemistry \& Behavior, 24, 525-529.

Postma, A., Meyer, G., Tuiten, A., van Honk, J., Kessels, R. P., \& ThiJssen, J. (2000). Effects of testosterone administration on selective aspects of object-location memory in healthy young women. Psychoneuroendocrinology, 25, 563-575.

Roselli, C. E. (1991). Sex differences in androgen receptors and aromatase activity in microdissected regions of the rat brain. Endocrinology, 128, 1310-1315.

Sfikakis, A., Spyraki, C., Sitaras, N., \& Varonos, D. (1978). Implication of estrous cycle on conditioned avoidance behavior in the rat. Physiology \& Behavior, 21, 441-446.

SHerwin, B. B. (1988a). A comparative analysis of the role of androgen in human male and female sexual behavior: Behavioral specificity, critical thresholds, and sensitivity. Psychobiology, 16, 416-425.

Sherwin, B. B. (1988b). Estrogen and/or androgen replacement therapy and cognitive functioning in surgically menopausal women. Psychoneuroendocrinology, 13, 345-357.

Sih, R., Morley, J. E., Kaiser, F. E., Perry, H. M., Patrick, P., \& Ross, C. (1997). Testosterone replacement in older hypogonadalmen: A 12-month randomized controlled trial. Journal of Clinical Endocrinology \& Metabolism, 82, 1661-1667.

Silverman, I., Kastuk, D., Choi, J., \& Phillips, K. (1999). Testosterone levels and spatial ability in men. Psychoneuroendocrinology, 24, 813-822.

Smith, E. E., Jonides, J., \& Koeppe, R. A. (1996). Dissociating verbal and spatial working memory using PET. Cerebral Cortex, 6, 11-20.

SQUIRE, L. R. (1992). Memory and the hippocampus: A synthesis from findings with rats, monkeys, and humans. Psychological Review, 99, 195-231.

Stackman, R. W., Blasberg, M. E., Langan, C. J., \& Clark, A. S. (1997). Stability of spatial working memory across the estrous cycle of Long-Evans rats. Neurobiology of Learning \& Memory, 67, 167-171. 
Stewart, J., Skvarenina, A, \& Pottier, J. (1975). Effects of neonatal androgens on open-field behavior and maze learning in the prepubescent and adult rats. Physiology \& Behavior, 14, 291-295.

VAndenheede, M., \& Bouissou, M. F. (1993). Effect of androgen treatment on fear reactions in ewes. Hormones \& Behavior, 27, 435-448.

van Goozen, S. H., Cohen-Kettenis, P. T., Gooren, L. J., Frijda, N. H. \& VAN DE Poll, N. E. (1994). Activating effects of androgens on cognitive performance: Causal evidence in a group of female-tomale transsexuals. Neuropsychologia, 32, 1153-1157.

Vazquez-Perey ra,F., Rivas-Arancibia, S., Loaeza-Del Castillo, A., \& SChNeIDER-Rivas, S. (1995). Modulation of short-term memory by steroid sex hormones. Life Sciences, 56, 255-260.

Venault, P., Chapouthier, G., De Carvalho, L. P., Simiand, J., Morre, M., DodD, R. H., \& Rossier, J. (1986). Benzodiazepine im- pairs and beta-carboline enhances performance in learning and memory tasks. Nature, 321, 864-866.

WARREN, S. G., \& JURASKA, J. M. (1997). Spatial and nonspatial learning across the rat estrous cycle. Behavioral Neuroscience, 111, 259-266.

Williams, C. L., Barnett, A., \& Meck, W. H. (1991). Organizational effects of early gonadal secretions on sexual differentiation in spatial memory. Behavioral Neuroscience, 104, 84-97.

Williams, C. L., \& MEcK, W. H. (1991). The organizational effects of gonadal steroids on sexually dimorphic spatial ability. Psychoneuroendocrinology, 16, 155-176.

(Manuscript received September 8, 2000; revision accepted for publication February 2, 2001.) 